\title{
Toxicity of Essential Oils Nanoemulsion Against Aphis craccivora and Their Inhibitory Activity on Insect Enzymes
}

\author{
Khaled Abdelaal 1,*(D), Mamdouh Essawy ${ }^{2}$, Attia Quraytam ${ }^{3}$, Fahmy Abdallah ${ }^{4}$, Heba Mostafa ${ }^{4}$, \\ Kamel Shoueir ${ }^{5, *}$, , Hatem Fouad ${ }^{4,6}$, Fahmy A. S. Hassan ${ }^{7}$ and Yaser Hafez ${ }^{1}$ (1)
}

1 EPCRS Excellence Center, Plant Pathology and Biotechnology Laboratory, Agricultural Botany Department, Faculty of Agriculture, Kafrelsheikh University, 33516 Kafrelsheikh, Egypt; hafezyasser@gmail.com

2 Economic Entomology Department, Faculty of Agriculture, Kafrelsheikh University, 33516 Kafrelsheikh, Egypt; mtmoad7@gmail.com

3 Pesticides Chemistry and Toxicity Department, Faculty of Agriculture, Kafrelsheikh University, 33516 Kafrelsheikh, Egypt; mf1037755@gmail.com

4 Agricultural Research Center, Plant Protection Research Institute, Dokki, 12622 Cairo, Egypt; khamoss181@gmail.com (F.A.); hebaghorab95@gmail.com (H.M.); moh588105@gmail.com (H.F.)

5 Institute of Nanoscience \& Nanotechnology, Kafrelsheikh University, 33516 Kafrelsheikh, Egypt

6 Ministry of Agriculture Key Lab of Molecular Biology of Crop Pathogens and Insect Pests, Institute of Insect Sciences, Zhejiang University, Zhejiang 310058, China

7 Department of Biology, College of Science, Taif University, P.O. Box 11099, Taif 21944, Saudi Arabia; ajareem81@gmail.com

* Correspondence: khaled.elhaies@gmail.com (K.A.); kameltag@yahoo.com or kamel_rezk@nano.kfs.edu.eg (K.S.); Tel.: +201016701839 (K.A.); +201002967836 (K.S.)

check for updates

Citation: Abdelaal, K.; Essawy, M.; Quraytam, A.; Abdallah, F.; Mostafa, H.; Shoueir, K.; Fouad, H.; Hassan, F.A.S.; Hafez, Y. Toxicity of Essential Oils Nanoemulsion Against Aphis craccivora and Their Inhibitory Activity on Insect Enzymes. Processes 2021, 9, 624. https://doi.org/ $10.3390 /$ pr9040624

Academic Editor: Urszula Bazylinska

Received: 9 February 2021

Accepted: 26 March 2021

Published: 1 April 2021

Publisher's Note: MDPI stays neutral with regard to jurisdictional claims in published maps and institutional affiliations.

Copyright: (c) 2021 by the authors. Licensee MDPI, Basel, Switzerland. This article is an open access article distributed under the terms and conditions of the Creative Commons Attribution (CC BY) license (https:/ / creativecommons.org/licenses/by/ $4.0 /)$.
Abstract: Essential oils are widely used as botanical insecticides rather than chemically synthesized pesticides which led to catastrophic effects on humans, the environment, and eutrophication. Here, encapsulation of four essential oils Basilicum ocimum, Cuminum cyminum, Origanum marjorana, and Matricaria chamomilla were utilized in the presence of $3 \% v / v$ ethanol, as anti-insect against Aphis craccivora and compared to traditional insecticides dinotefuran and pymetrozine. Different tools were used to characterize the prepared nanoemulsion such as TEM, SEM, and Zeta potential analyzer. Besides, selected B. ocimum and C. cyminum were analyzed by gas chromatography-mass GC/mass spectrometry. The results reveal that nanoemulsion exhibited considerable toxic activities against laboratory and field strains of cowpea aphid. In the toxicity bioassay test of essential oils, moderate mortality was observed at $10,000 \mathrm{mg} / \mathrm{L}$ against aphid with lethal concentration that kills $50 \%$ of insects ( $\mathrm{LC}_{50}$ ) values of basil $992 \mathrm{mg} / \mathrm{L}$ and marjoram $3162 \mathrm{mg} / \mathrm{L}$. Else, nanoemulsion provided the highest mortality rate at $625 \mathrm{mg} / \mathrm{L}$ and the $\mathrm{LC}_{50}$ values of basil nanoemulsion (NE) $45 \mathrm{mg} / \mathrm{L}$, and marjoram NE $188 \mathrm{mg} / \mathrm{L}$ in laboratory strains. The systemic effects of the tested substances acetylcholine esterase, alkaline phosphatase, $\beta$-esterases, glutathione S-transferase (GST), and mixed-function oxidase (MFO) enzymes on insects were found to be significantly decreased and increased when compared with control groups. Overall, these results highlight that the nanoemulsion is potential tools to control cowpea aphid and could be useful in developing integrated insect management in faba bean fields.

Keywords: essential oil; nanoemulsion; cowpea aphis; GC/mass spectrometry; bioassay test; detoxification enzymes

\section{Introduction}

The cowpea aphid (Aphis craccivora) is one of the most harmful insects for many crops all over the world [1]. The cowpea aphid insects cause significant economic injuries by sucking sap from leaves, pods, and other organs or through the transmission of major viruses such as bean leaf roll virus (BLRV) [2]. The common method for A. craccivora control is chemical insecticides, but the large-scale use of synthetic insecticides resulted 
in the development of resistance to insecticides and out-break of secondary pests [3,4]. Additionally, the impact of some pesticide residues and direct hazards on the users were impacted on the environment and non-target organisms like parasitoids and aphid insects [5]. However, many researchers preferred natural compounds due to their less harmful nature to non-target organisms. Plant extracts and essential oils (EOs) may be an alternative to synthetic insecticides because they are effective, eco-friendly, and easily biodegradable [6-8]. Improve metabolic detoxification by glutathione-S-transferases, esterases, P450 monooxygenases, and alkaline phosphatase are major factors in resistance to insecticides in many aphid species $[9,10]$. Therefore, the researchers in the insects' control field are seeking some alternative insecticides, which are more effective against the pest, have little cytotoxic effects on natural enemies, and slightly toxic to the environment [11,12]. Essential oils from plant species are mixtures of low molecular weight, produced in high amounts by an array of many plant families such as Apiaceae, Asteraceae, Lamiaceae, Lauraceae, Rutaceae, and Myrtaceae [13-15], furthermore, their monoterpenoids have attracted attention in last years as potential pest control agents. Therefore, these components had variable modes of action such as direct toxicants, antifeedants/repellants, and some effects on the enzymatic profiles [16]. Though, the efficacy of botanical insecticides may lower than synthetic insecticides, but they are prophylactic and they are not harmful on the environment and public health $[17,18]$.

Some problems of essential oils were shown when used as pesticides such as limited physical stability, quick degradation in the environment, and poor water solubility. Therefore, there are some methods to overcome these problems with nanotechnologies such as nanoemulsion which, improves the physical stability of essential oil, water diffusion, and covering with small-sized oil droplets of the targeted surface area [19-22]. So, biological nanomaterial has taken a vast role in pest and plant disease management [23-26]. Therefore, this work was designed to study the susceptibility of $A$. craccivora to some of the new and non-traditional insecticides belongs to different groups of essential oils and their nanoemulsions. The production and properties of the fabricated nanoemulsions were verified by UV-vis spectrophotometry, transmission electron microscopy (TEM), scanning electron microscopy (SEM), and energy-dispersive X-ray (EDX) spectroscopy techniques. Moreover, the activity of some detoxification enzymes like acetylcholinesterase (AChE), $\beta$-esterases, glutathione S-transferase (GST), alkaline phosphatase, and mixed-function oxidase (MFO) was studied in field strain.

\section{Materials and Methods}

\subsection{Chemicals, Reagents, and Essential Oils}

The essential oils of Basilicum ocimum (basil), Cuminum cyminum (cumin), Origanum marjorana (marjoram), and Matricaria chamomilla (chamomile) were obtained from Hashem Brothers Company for essential oils and aromatic products, Kalyoubeya, Egypt. Pymetrozine (Chess 50\% WG) belongs to pyridine azomethine derivatives and Dinotefuran (Oshin 20\% SG) belongs to neonicotinoid groups were purchased from Syngenta and Mitsui Chem., Egypt. Acetylcholine iodide, 5,5-dithiobis-2-nitro benzoic acid, fast blue salt, ( $\beta$-esterases), GST, alkaline phosphatase, Folin-Ciocalteau reagent were obtained from Sigma-Aldrich Chemicals (St Louis, MO, USA) and all other chemicals, as well as reagents used, were of the highest analytical grade purchased from local companies.

\subsection{Preparation and Characterization of Nanoemulsions}

In this study, the essential oil nanoemulsions were prepared, according to the method of [19] with some modifications by [20]. Thickened (O/W) nanoemulsions were prepared with essential oils, each representing $(14 \%,(v / v)$ of the total coarse emulsion), ethanol $3 \%(v / v)$, and Tween $80(3 \%, v / v)$, representing $20 \%(v / v)$ of the total emulsion. The components of the oil phase were vigorously mixed for $2 \mathrm{~h}$. Then, they were mixed with water $(80 \%)$, kept for $3 \mathrm{~min}$, and finally centrifuged at $3000 \mathrm{rpm}$ for $10 \mathrm{~min}$. The essential oils nanoemulsion were stored in dark bottles at ambient temperature. The color of 
nanoemulsion was changed and directly characterized by UV-vis. The UV spectra were recorded on (Shimadzu UV-2550 spectrophotometer, Kyoto, Japan) at $1 \mathrm{~cm}$ optical path quartz cuvette, in the range of 200-800 nm. Furthermore, an aliquot of nanoemulsions containing nanoparticles was used for investigation of the morphology and nanoparticle size by SEM using (JEOL-JSM IT-100, Tokyo, Japan) and operated at an accelerating voltage of $10 \mathrm{kV}$. The presence of metals was also confirmed by the energy dispersive spectroscopy (EDS) instrument equipped with the SEM. The samples were diluted to 50-folds in double deionized water and dried under vacuum at room temperature. Subsequently, the samples were coated using sputter before analysis. While the structure of synthesized nanoemulsions was observed by the TEM using a JEOL-1230, Japan transmission electron microscope operated at an accelerating voltage of $300 \mathrm{kV}$. TEM samples were prepared by placing a few drops of the emulsion-nanoparticles onto a carbon-coated copper grid to make a thin film of the sample and then it was kept in a grid box sequentially.

\subsection{Droplet Size Analysis}

Regarding the nanoemulsions characterization, the average size distributions of nanoemulsions were noted in the light of their intensity, number weight, and volume, respectively. Zeta potential, conductivity, viscosity, and polydispersity index (PDI) were investigated by photon correlation spectroscopy using a Zeta Plus tool (Zeta sizer, Brookhaven Instruments Corp New York, NY, USA).

\subsection{Analysis of Volatiles in Essential Ooils and Nanoemulsions}

The GC-MS analysis was carried out using gas chromatography-mass spectrometry instrument stands with the following specifications, under a TRACE GC Ultra Gas Chromatographs instrument (THERMO Scientific Corp Carlsbad, CA, USA), coupled with a Thermo mass spectrometer detector (ISQ Single Quadrupole Mass Spectrometer. Germering, Germany). The GC-MS system was equipped with a TR-5 MS column (30 m by $0.32 \mathrm{~mm}$ i.d., $0.25 \mu \mathrm{m}$ film thickness). Analyses were carried out using helium as carrier gas at a flow rate of $1 \mathrm{~mL} / \mathrm{min}$ and a split ratio of 1:10 using the following temperature program: $60^{\circ} \mathrm{C}$ for $1 \mathrm{~min}$, rising at $4 \mathrm{oC} / \mathrm{min}$ to $240{ }^{\circ} \mathrm{C}$ and held for $1 \mathrm{~min}$. The injector and detector were held at $210^{\circ} \mathrm{C}$. Diluted samples $(1: 10$ hexane, $v / v)$ of $1 \mu \mathrm{L}$ of the mixtures were always injected. The spectra were obtained by electron ionization (EI) at $70 \mathrm{eV}$, using a spectral range of $\mathrm{m} / \mathrm{z} 40-450$. The identification of the chemical constituents of the essential oil was de-convoluted using AMDIS software (AMDIS version 2.70, www.amdis.net, accessed on 29 March 2021) and identified by its retention indices (relative to n-alkanes C8-C22), mass spectrum matching to [authentic standards (when available), Wiley spectral library collection, and NSIT library database].

\subsection{Aphid Rearing}

A laboratory strain of A. craccivora was obtained from the laboratory of sucking insects department, Plant Protection Research Institute, ARC, and Egypt. This strain reared on faba bean seedling (Sakh3) grown in plastic pots (20 cm diameter) under laboratory conditions of $25 \pm 1{ }^{\circ} \mathrm{C}, 65 \% \mathrm{RH}$, and $12 \mathrm{~h}$ daily illumination by two fluorescent bulbs of 40 watts. Every week, the seedlings were replaced with new ones to keep aphid colonies alive. This laboratory strain was used as a reference strain. In the case of the field strain, faba bean leaves infested with aphids were collected from faba bean fields at Sakha Agricultural Research Station Farm, Kafr El-Sheikh governorate, Egypt, and moved to the laboratory to complete the toxicity tests2.6. Toxicity Tests

The rapid test was used to compare the susceptibility of the laboratory and field strains of aphids to different compounds of essential oils [21], their nanoemulsions, and two chemical insecticides (pymetrozine and dinotefuran). Where, batches of aphids were immersed and tested with serial concentrations $(625,1250,2500,5000,7500$, and 10,000 mg/L) of essential oils and $(39.063,78.125,156.25,312.5,468.75$, and $625 \mathrm{mg} / \mathrm{L})$ of nanoemulsions for $10 \mathrm{~s}$ and the excess of the solution was dried on paper towels. For each strain, twenty-five 
apterous adults of the same ages and sizes were placed on leaves of faba bean plants in Petri-dishes $(9 \mathrm{~cm})$ with the help of a soft brush, while control treatments aphids were immersed in ethanol and distilled water (20:80). Three replicates were used for each concentration of the tested compound and the control. All Petri-dishes were maintained under laboratory conditions of $25 \pm 2{ }^{\circ} \mathrm{C} ; 65 \pm 5 \%$ relative humidity and $12 \mathrm{~h}$ daily illumination by 2 fluorescent bulbs of $40 \mathrm{wt}$. Mortality counts were observed after 24, 48, and $72 \mathrm{~h}$ according to the toxicant's mode of action, and the insect was considered alive if it was able to move at least one leg or antennae during probing with a soft brush. The aphid was considered dead if there's no movement or only very slight twitching observed [22]. Mortality percentages were adjusted for mortality in control according to Abbott's formula [23]. The data were analyzed according to [24] to calculate values of the lethal concentration that kills $50 \%$ of insects $\left(\mathrm{LC}_{50}\right)$, lethal concentration that kills $90 \%$ of insects $\left(\mathrm{LC}_{90}\right)$, and slope for the tested compounds. The potency level expressed as several folds were calculated by dividing the $\mathrm{LC}_{50}$ for the low effectiveness materials by the corresponding figure for each compound.

\subsection{Biochemical Aspects}

The activity of AChE was determined and the nonspecific esterases ( $\beta$-esterases) was recognized by [25], GST by [26], alkaline phosphatase by [27], and MFO by [28], and all assayed in field strains of exposure insects with minor modifications. The insects were prepared as described by [29] and homogenized with cold phosphate buffer $\mathrm{pH} 7.2$ $(50 \mathrm{mg} / \mathrm{L} \mathrm{mL})$ using a glass homogenizer. The cold crude extracts were centrifuged at $8000 \mathrm{rpm}$ for $15 \mathrm{~min}$ at $2{ }^{\circ} \mathrm{C}$ in a refrigerated centrifuge and passed through glass wool to remove the last of insoluble cell debris. The resulting supernatant of homogenate was collected as a source of the measured biochemical aspects and kept at $-20^{\circ} \mathrm{C}$ for further enzyme analysis.

\subsection{Statistical Analysis}

The percentage of mortality for aphid insects treated with essential oils, their nanoemulsions, and two chemical insecticides were subjected to probit analysis (Finney, 1971) for calculating $\mathrm{LC}_{50}, \mathrm{LC}_{90}$ statistics at $95 \%$ confidence limits of lower and upper values. The differences between enzyme activities in the field strain were assessed with LSD (the least-significant-difference test) and Duncan at a $5 \%$ level of probability. Chi-square values were calculated using the SPSS software package 19.0 version (SPSS Inc., Chicago, IL, USA). The statistical analyses were performed using GenStat18 software (VSN International, 2015).

\section{Results and Discussions}

\subsection{Characterization of the Nanoemulsion \\ 3.1.1. Electronic Spectrum}

In the present investigation, the materials of essential oils underwent reduction, which indicated the formation of nanoemulsions (Figure 1). The presence of emulsion nanoparticles was affirmed and measured by utilizing UV spectrophotometer. The formation was shown at the absorption peak of basil (Figure 1A), chamomile (Figure 1B), marjoram (Figure 1C), and cumin (Figure 1D), respectively. Such characteristics match well with those observed for a single surface plasmon resonance (SPR) and the deviation of the SPR shoulder of anisotropic particles might be possibly attributable to their shape and size $[8,11,30]$. 


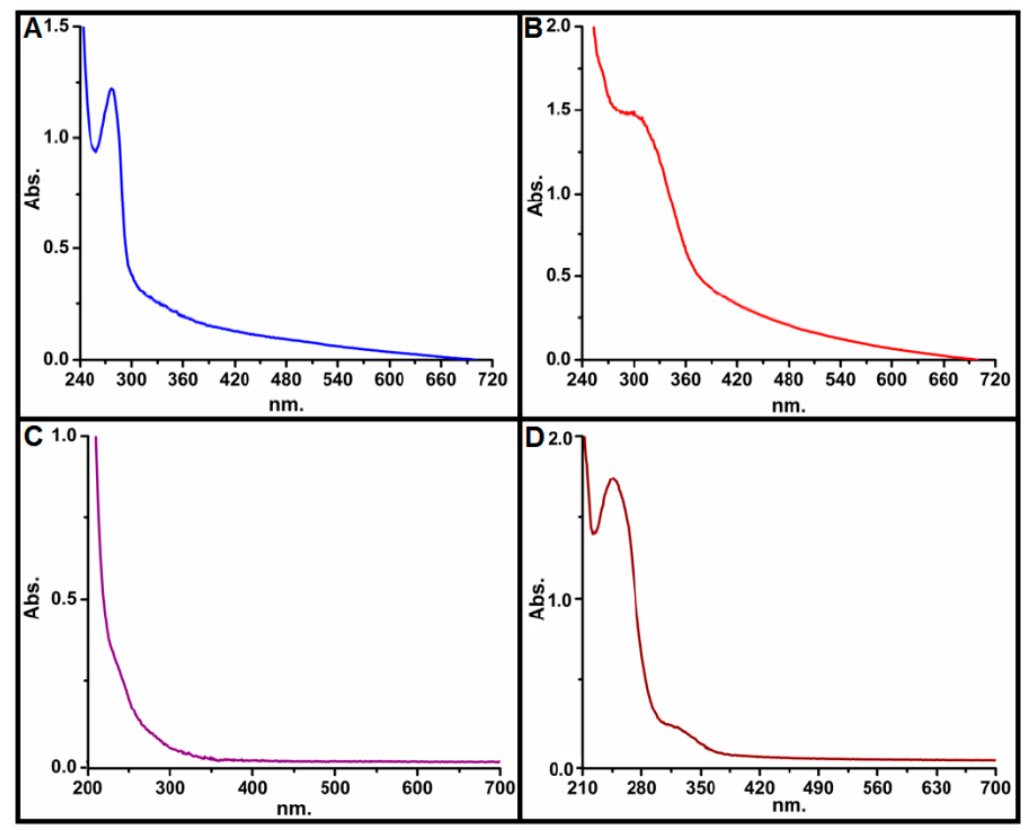

Figure 1. UV spectrophotometer fingerprint peaks of prepared (A) basil, (B) chamomile, (C) marjoram, and (D) cumin.

\subsubsection{Morphological Structure}

Figure 2 showed the TEM images of the prepared nanoemulsion-based essential oils with polydispersity character. The TEM images indicated that the synthesized emulsion nanoparticles are mainly uniform with a spherical shape. The transparent organic layer coatings around the nanoparticles were shown in the TEM image, which was due to the phytochemicals that served as a capping agent. Therefore, the particles were polydispersed with direct contact and stable for a long period to prevent agglomeration [31].
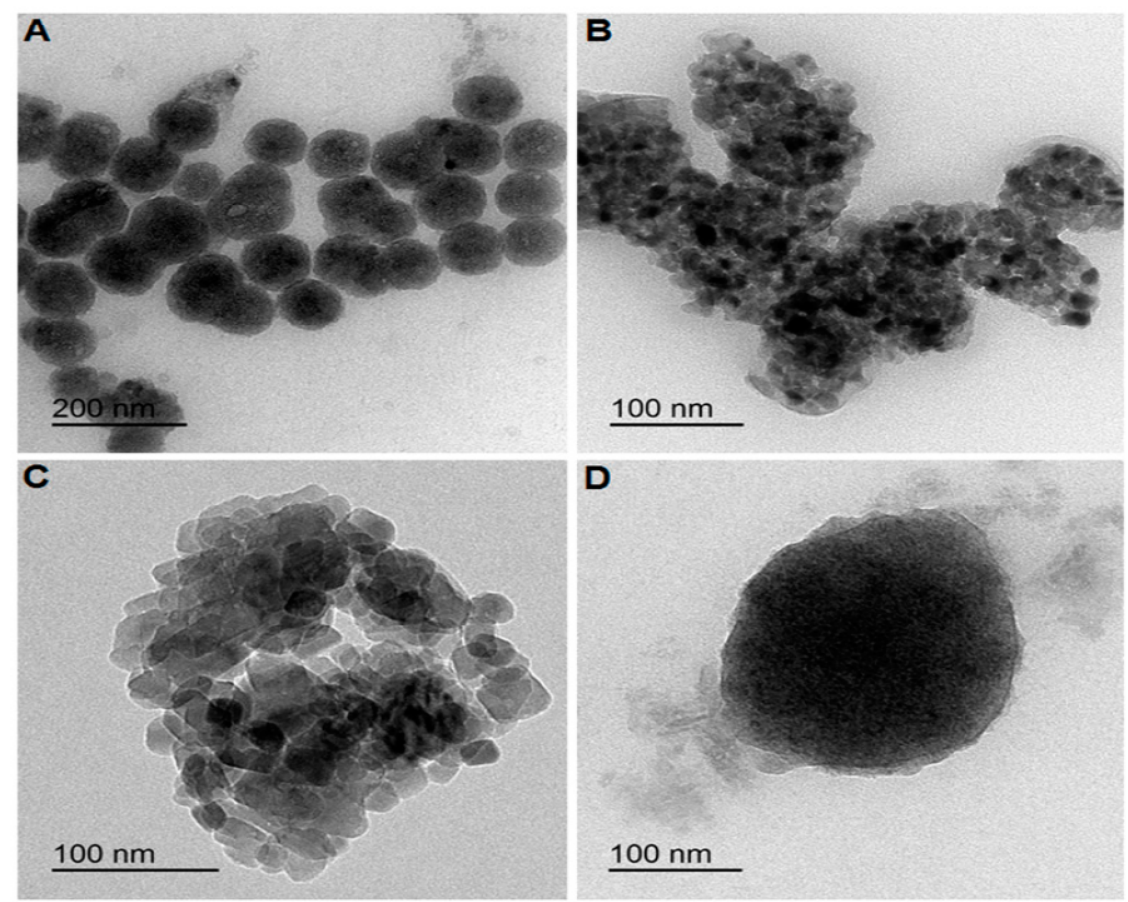

Figure 2. TEM image of (A) basil nanoemulsions, (B) chamomile nanoemulsions, (C) marjoram nanoemulsions, and (D) cumin nanoemulsions. 
The surface morphology of basil nanoemulsion as an example after lyophilization was detected by SEM analysis as in Figure 3 . The nanoemulsions are mainly spherically shaped with an average range of particle size from 15.8 to $99.8 \mathrm{~nm}$, and this is a good resemblance with the shape of the SPR band observed in the UV-Vis spectra [32]. The EDX pattern of nanoemulsions was shown in (Figure 3B). The presence of strong peaks of different elements after $3 \mathrm{keV}$ was observed, which indicates that the $\mathrm{Ca}, \mathrm{Cu}, \mathrm{Zn}, \mathrm{K}$, and $\mathrm{Mg}$ are the major elements in nanoemulsions, thus confirming the successful biosynthesis of nanoemulsions. A similar peak after $(3 \mathrm{keV})$ has been reported by other researchers [33].

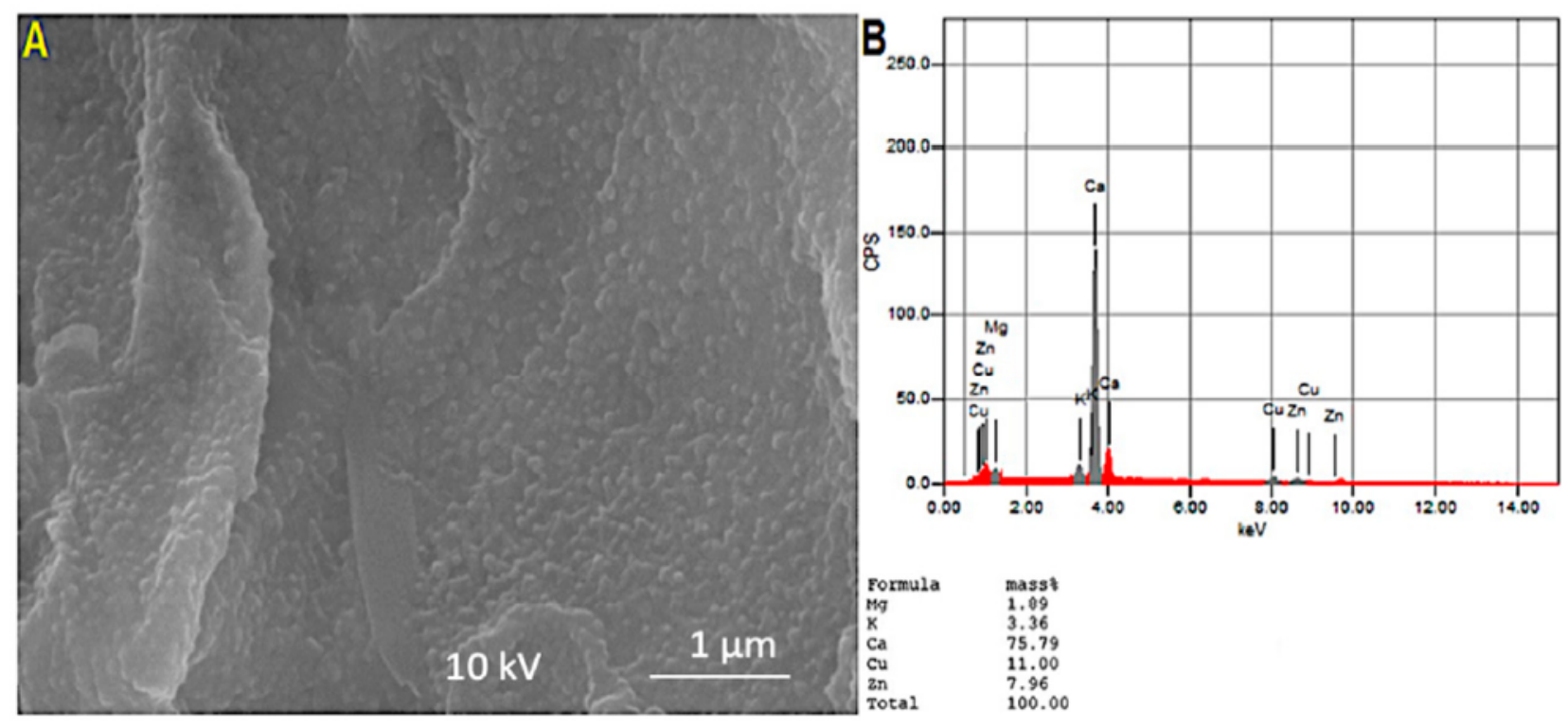

Figure 3. (A) SEM morphology and (B) EDX elemental analysis of selected basil nanoemulsion.

\subsubsection{Size Distribution Analysis}

The zeta potential is usually utilized to know the constancy of colloidal systems. The zeta potential of nanoparticles was evaluated in water as a dispersant. In this report, zeta potentials of basil nanoemulsions, chamomile nanoemulsions, marjoram nanoemulsions, and cumin nanoemulsions were $-26.2 \mathrm{mV},-34.9 \mathrm{mV},-15.8 \mathrm{mV}$, and $-29.4 \mathrm{mV}$, which denoted the stability of emulsion nanoparticles suspensions (Figure $4 \mathrm{~A}-\mathrm{D}$ ). The average size of basil emulsion nanoparticles was found to be $129.5 \pm 1.3 \mathrm{~nm}$, PDI $=0.28$, chamomile emulsion nanoparticles $149.6 \pm 1.7 \mathrm{~nm}$, PDI $=0.54$, marjoram emulsion nanoparticles $182.1 \pm 1.8 \mathrm{~nm}, \mathrm{PDI}=0.22$ and cumin emulsion nanoparticles $172.7 \pm 1.5 \mathrm{~nm}, \mathrm{PDI}=0.37$ (Table 1). Mostly, the suspension that displays an absolute zeta potential less than $20 \mathrm{mV}$ is considered unstable and will cause precipitation of particles from solution, while the absolute zeta potential higher than $20 \mathrm{mV}$ is stable [34,35]. In another scenario, the average particle size calculated using dynamic light scattering measurements (DLS) was found to be lower than $300 \mathrm{~nm}$ as a nanoemulsion [36]. Nanoemulsion having a particle size in the range of 100-400 nm demonstrated beneficial attributes, such as permeability, thermal stability, and solubility [34,37]. Additionally, it revealed the smallest Z-average size of $129.5 \pm 1.3 \mathrm{~nm}$ and the lowest conductivity $0.26 \mathrm{mS} / \mathrm{cm}$. 


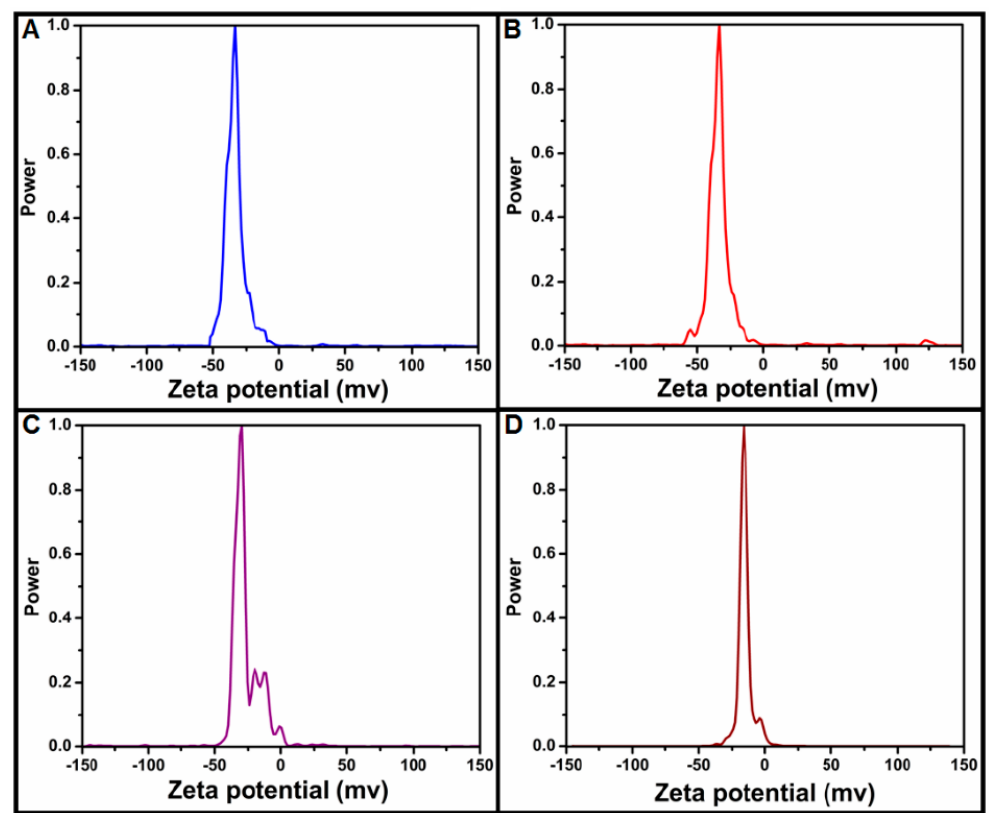

Figure 4. Zeta potential distributions for (A) basil nanoemulsion, (B) chamomile nanoemulsion, (C) marjoram nanoemulsion, and (D) cumin nanoemulsion, respectively.

Table 1. Mean $\pm(\mathrm{SD})$ particle size diameter (nm), polydispersity index (PDI), and conductivity measurements of nanoemulsion based oils.

\begin{tabular}{cccc}
\hline Nanoemulsions & $\begin{array}{c}\text { Particle Diameter } \\
(\mathbf{n m})\end{array}$ & $\begin{array}{c}\text { Polydispersity Index } \\
\text { PDI }\end{array}$ & $\begin{array}{c}\text { Conductivity } \\
\text { (ms/cm) }\end{array}$ \\
\hline B. ocimum & $129.5 \pm 1.3$ & 0.28 & 0.26 \\
M. chamomilla & $149.6 \pm 1.7$ & 0.54 & 0.28 \\
O. marjorana & $182.1 \pm 1.8$ & 0.22 & 0.28 \\
C. cyminum & $172.7 \pm 1.5$ & 0.37 & 0.29 \\
\hline
\end{tabular}

\subsubsection{GC-MS Analysis and Identification of Components}

A total of 14 components were determined in basil, C. cumin EO, and in their nanoemulsion by GC-MS analysis (Tables 2 and 3). Interestingly, the major components in basil oil were linalool (22.91\%), eucalyptol (19.18\%), eugenol (6.89\%), 1,6-octadien-3-ol, 3,7dimethyl- (6.56\%), $\alpha$-bergamotene $(6.39 \%)$, cadinol T(2.95\%), and $\gamma$-cadinene $(2.55 \%)$. However, the major components in cumin oil were $\gamma$-terpinene (22.25\%) L- $\beta$-pinene $(21.63 \%)$, $\alpha$-terpinene $(19.31 \%)$, cumic aldehyde (13.02\%), and $\beta$-cymene (8.78\%) (Table 2). In our study, the insecticidal activity of basil and cumin essential oils may be attributed to the high level of these components (Table 2). On the other hand, the high levels of components in basil-nanoemulsions were $\alpha$-bergamotene (24.73\%) and linalool (10.12\%). Moreover, in cumin-nanoemulsions, the high level of components was cumic aldehyde (57.28\%), $\beta$-cymene (18.32\%), and $\alpha$-terpinene (9.91\%) (Table 3). The major constituents of the basil and cumin EOs were similar to these oils which, were isolated from basil and cumin plants growing in Egypt or other countries [38-40]. Methyl chavicol, linalool, and geranial were reported as the major active components in basil oil. Linalool is characterized as the main component from basil essential oil with $(22.91 \%)$, and it is an effective component as a contact insecticide and feeding deterrent [41]. Therefore, this can explain the advantage of the toxicity of basil and cumin compared to other tested essential oils. 
Table 2. Volatile components obtained from basil and cumin oils.

\begin{tabular}{|c|c|c|c|c|c|}
\hline \multirow{2}{*}{ Compounds } & \multirow{2}{*}{ Other Names } & \multirow{2}{*}{$\mathrm{RT}^{\mathrm{a}}$ (min) } & \multirow{2}{*}{$\begin{array}{l}\text { Molecular } \\
\text { Formula }\end{array}$} & \multicolumn{2}{|c|}{ Concentrations \% } \\
\hline & & & & Basil Oil & Cumin Oil \\
\hline $\begin{array}{c}\text { Bicyclo[3.1.1]heptane,6,6- } \\
\text { dimethyl-2-methylene-, } \\
\text { (1s)- }\end{array}$ & L- $\beta$-Pinene & 6.55 & $\mathrm{C}_{10} \mathrm{H}_{16}$ & - & 21.63 \\
\hline Benzene, methyl(1-methylethyl)- & $\beta$-Cymene & 7.46 & $\mathrm{C}_{10} \mathrm{H}_{14}$ & - & 8.78 \\
\hline Eucalyptol & - & 7.68 & $\mathrm{C}_{10} \mathrm{H}_{18} \mathrm{O}$ & 19.18 & - \\
\hline $\begin{array}{c}\text { 2-oxabicyclo[2.2.2]octane, } \\
\text { 1,3,3-trimethyl- }\end{array}$ & furan & 7.81 & $\mathrm{C}_{10} \mathrm{H}_{18} \mathrm{O}$ & 5.58 & - \\
\hline $\begin{array}{c}\text { 1,4-cyclohexadiene, } \\
\text { 1-methyl-4-(1-methylet hyl)- }\end{array}$ & $\gamma$-Terpinen & 8.38 & $\mathrm{C}_{10} \mathrm{H}_{16}$ & - & 22.25 \\
\hline Linalool & - & 9.93 & $\mathrm{C}_{10} \mathrm{H}_{18} \mathrm{O}$ & 22.91 & - \\
\hline 1,6-octadien-3-ol,3,7-dimethyl- & Linalool & 10.27 & $\mathrm{C}_{10} \mathrm{H}_{18} \mathrm{O}$ & 6.56 & - \\
\hline Benzaldehyde, 4-(1-methylethyl)- & Cumic aldehyde & 12.17 & $\mathrm{C}_{10} \mathrm{H}_{12} \mathrm{O}$ & - & 13.02 \\
\hline $\begin{array}{l}\text { 4-Isopropyl cyclohexa-1,3-dien } \\
\text { ecarbaldehyde }\end{array}$ & $\alpha$-Terpinene & 13.63 & $\mathrm{C}_{10} \mathrm{H}_{14} \mathrm{O}$ & - & 19.31 \\
\hline Eugenol & - & 14.75 & $\mathrm{C}_{10} \mathrm{H}_{12} \mathrm{O}_{2}$ & 6.89 & - \\
\hline $\begin{array}{l}\text { Bicyclo[3.1.1]hept-2-ene, } \\
\text { 2,6-dimethyl-6-(4-methyl-3- } \\
\text { pentenyl)- }\end{array}$ & $\alpha$-Bergamotene & 15.89 & $\mathrm{C}_{15} \mathrm{H}_{24}$ & 6.39 & - \\
\hline $\begin{array}{l}\text { (1R,2S,6S,7S,8S)-8-Isopropyl-1- } \\
\text { methyl-3- } \\
\text { methylenetricyclo[4.4.0.02,7]decane- } \\
\text { rel- }\end{array}$ & $\beta$-Copaen- $4 \alpha$-ol & 16.66 & $\mathrm{C}_{15} \mathrm{H}_{24}$ & 1.58 & - \\
\hline $\begin{array}{c}\text { Naphthalene, } \\
\text { 1,2,3,4,4a,5,6,8a-octahydro-7-m } \\
\text { ethyl-4-methylene-1-(1-methyl } \\
\text { ethyl)- }\end{array}$ & $\gamma$-Cadinene & 17.25 & $\mathrm{C}_{15} \mathrm{H}_{24}$ & 2.55 & - \\
\hline tau.-Cadinol & Cadinol T & 19.25 & $\mathrm{C}_{15} \mathrm{H}_{26} \mathrm{O}$ & 2.95 & - \\
\hline
\end{tabular}

${ }^{\text {a }} \mathrm{RT}$, Retention time (minutes).

Table 3. Volatile components obtained from basil and cumin nanoemulsions.

\begin{tabular}{|c|c|c|c|c|c|}
\hline \multirow{2}{*}{ Compound } & \multirow{2}{*}{ Other Names } & \multirow{2}{*}{$\begin{array}{l}\text { RTa } \\
\text { (min) }\end{array}$} & \multirow{2}{*}{$\begin{array}{l}\text { Molecular } \\
\text { formula }\end{array}$} & \multicolumn{2}{|c|}{ Concentrations \% } \\
\hline & & & & Basil NE & Cumin NE \\
\hline $\begin{array}{c}\text { Bicyclo[3.1.1]heptane,6,6- } \\
\text { dimethyl-2-methylene- }\end{array}$ & $\beta$-Pinene & 6.28 & $\mathrm{C}_{10} \mathrm{H}_{16}$ & 2.65 & 5.53 \\
\hline Benzene, methyl(1-methylethyl)- & $\beta$-Cymene & 7.25 & $\mathrm{C}_{10} \mathrm{H}_{14}$ & 1.12 & 18.23 \\
\hline Eucalyptol & Eucalyptol & 7.38 & $\mathrm{C}_{10} \mathrm{H}_{18} \mathrm{O}$ & 2.65 & - \\
\hline $\begin{array}{c}\text { 1,4-cyclohexadiene, } \\
\text { 1-methyl-4-(1-methylethyl) }\end{array}$ & $\gamma$-Terpinen & 7.88 & $\mathrm{C}_{10} \mathrm{H}_{16}$ & - & 2.20 \\
\hline ç-Terpinene & ç-Terpinene & 7.91 & $\mathrm{C}_{10} \mathrm{H}_{16}$ & 1.29 & - \\
\hline Linalool & Linalool & 9.03 & $\mathrm{C}_{10} \mathrm{H}_{18} \mathrm{O}$ & 10.12 & - \\
\hline Benzaldehyde,4-(1-methylethyl)- & Cumic aldehyde & 11.81 & $\mathrm{C}_{10} \mathrm{H}_{12} \mathrm{O}$ & - & 57.28 \\
\hline Bornyl acetate & Bornyl acetate & 12.46 & $\mathrm{C}_{12} \mathrm{H}_{20} \mathrm{O}_{2}$ & 1.06 & - \\
\hline $\begin{array}{c}\text { 4-Isopropyl } \\
\text { cyclohexa-1,3-dienecarbaldehyde }\end{array}$ & $\alpha$-Terpinene & 12.57 & $\mathrm{C}_{10} \mathrm{H}_{14} \mathrm{O}$ & - & 9.91 \\
\hline p-Cymen-7-ol & p-Cymen-7-ol & 12.67 & $\mathrm{C}_{10} \mathrm{H}_{14} \mathrm{O}$ & - & 6.11 \\
\hline Eugenol & Eugenol & 13.90 & $\mathrm{C}_{10} \mathrm{H}_{12} \mathrm{O}_{2}$ & 2.57 & - \\
\hline
\end{tabular}


Table 3. Cont.

\begin{tabular}{|c|c|c|c|c|c|}
\hline \multirow{2}{*}{ Compound } & \multirow{2}{*}{ Other Names } & \multirow{2}{*}{$\begin{array}{l}\text { RTa } \\
(\min )\end{array}$} & \multirow{2}{*}{$\begin{array}{l}\text { Molecular } \\
\text { formula }\end{array}$} & \multicolumn{2}{|c|}{ Concentrations \% } \\
\hline & & & & Basil NE & Cumin NE \\
\hline $\begin{array}{l}\text { Bicyclo[3.1.1]hept-2-ene, } \\
\text { 2,6-dimethyl-6-(4-methyl-3- } \\
\text { pentenyl)- }\end{array}$ & $\alpha$-Bergamotene & 15.53 & $\mathrm{C}_{15} \mathrm{H}_{24}$ & 24.73 & - \\
\hline $\begin{array}{l}\text { Naphthalene,1,2,3,4,4a,5,6,8a- } \\
\text { octahydro-7- } \\
\text { methyl-4-methylene-1-(1- } \\
\text { methylethyl)-, } \\
(1 \alpha, 4 \mathrm{a} \beta, 8 \mathrm{a} \alpha)-\end{array}$ & $\gamma$-Cadinene & 16.93 & $\mathrm{C}_{15} \mathrm{H}_{24}$ & 9.67 & - \\
\hline tau.-Cadinol & Cadinol T & 18.91 & $\mathrm{C}_{15} \mathrm{H}_{26} \mathrm{O}$ & 5.64 & - \\
\hline
\end{tabular}

RTa-retention time (minutes).

\subsection{Susceptibility of A. Craccivora toTtested Insecticides}

In this study, we compared the toxicity of two insecticides: Pymetrozine (Chess $50 \%$ WG), Dinotefuran (Oshin 20\%SG), and four essential oils basil, cumin, marjoram, and chamomile as well as their nanoemulsions against apterous adult stage of laboratory and field strains of aphid A. craccivora. Where, data in (Table 4) cleared that pymetrozine and dinotefuran were the most effective against laboratory strains of $A$. craccivora with $\mathrm{LC}_{50}$ ( 9.4 and $4.6 \mathrm{mg} / \mathrm{L}$ ), respectively. Furthermore, (Table 4) showed that the toxicity of essential oils and nanoemulsion of four essential oils, where basil was the most effective oil followed by cumin, whereas chamomile and marjoram oils were the least effective after different exposure times against the laboratory strains of $A$. craccivora with $\operatorname{LC}_{50}(992,1710,2327$, and $3162 \mathrm{mg} / \mathrm{L}$ ), respectively. Furthermore, the toxicity activity of nanoemulsions for four essential oils against the laboratory strains of $A$. craccivora demonstrated the same results of essential oils but with low concentrations and $\mathrm{LC}_{50}$ were $(45,79,134$, and $188 \mathrm{mg} / \mathrm{L})$, respectively (Table 4). Moreover, the data in Table 4 showed that the highest degree of homogeneity for the laboratory population of $A$. craccivora was observed to basil with a slope value of 2.1 and 1.9 for EOs and nanoemulsion (NE), respectively, while the other tested compounds exhibited low slope values, and this indicates heterogeneity in the aphid response to these essential oils. On the other hand, in field strain, basil oil, and their nanoemulsions were the most effective on $A$. craccivora where recorded $\mathrm{LC}_{50}$ values 1376 and $54 \mathrm{mg} / \mathrm{L}$, followed by cumin with $\mathrm{LC}_{50}$ values 2263 and $83 \mathrm{mg} / \mathrm{L}$ after $72 \mathrm{~h}$ of exposure.

Table 4. Toxicity of four essential oils, nanoemulsions, and chemical insecticides against $A$. craccivora laboratory strains.

\begin{tabular}{|c|c|c|c|c|c|c|c|c|c|c|}
\hline \multirow{2}{*}{ Treatments } & \multicolumn{2}{|c|}{$\begin{array}{c}\mathrm{LC}_{50} \mathrm{mg} / \mathrm{L} \\
(95 \% \mathrm{LCL}-\mathrm{UCL})\end{array}$} & \multicolumn{2}{|c|}{$\begin{array}{c}\mathrm{LC}_{90} \mathrm{mg} / \mathrm{L} \\
(95 \% \mathrm{LCL}-\mathrm{UCL})\end{array}$} & \multicolumn{2}{|c|}{ Slope \pm SE } & \multicolumn{2}{|c|}{$x^{2}$} & \multicolumn{2}{|c|}{ PL } \\
\hline & EO & NE & EO & NE & EO & NE & EO & $\mathrm{NE}$ & EO & NE \\
\hline $\begin{array}{c}O . \\
\text { basilicum }\end{array}$ & $\begin{array}{c}992 \\
(820-1163)\end{array}$ & $\begin{array}{c}45 \\
(35-55)\end{array}$ & $\begin{array}{c}3998 \\
(3358-4969)\end{array}$ & $\begin{array}{c}209 \\
(176-256)\end{array}$ & $2.1 \pm 0.17$ & $1.9 \pm 0.17$ & 2.9 & 1.8 & 3.2 & 69.5 \\
\hline C. cyminum & $\begin{array}{c}1710 \\
(1462-1967)\end{array}$ & $\begin{array}{c}79 \\
(65-94)\end{array}$ & $\begin{array}{c}7600.32 \\
(6282-9650)\end{array}$ & $\begin{array}{c}425 \\
(349-545)\end{array}$ & $1.9 \pm 0.15$ & $1.8 \pm 0.14$ & 3.5 & 2.8 & 1.9 & 39.7 \\
\hline $\begin{array}{c}\text { M. } \\
\text { chamomilla }\end{array}$ & $\begin{array}{c}2327 \\
(2024-2653)\end{array}$ & $\begin{array}{c}134 \\
(114-155)\end{array}$ & $\begin{array}{c}9962.66 \\
(8160-12821)\end{array}$ & $\begin{array}{c}726 \\
(572-990)\end{array}$ & $2.0 \pm 0.15$ & $1.9 \pm 0.14$ & 1.9 & 1.8 & 1.4 & 23.5 \\
\hline $\begin{array}{c}O . \\
\text { marjorana }\end{array}$ & $\begin{array}{c}3162 \\
(2753-3624)\end{array}$ & $\begin{array}{c}188 \\
(163-216)\end{array}$ & $\begin{array}{c}14862 \\
(11736-20206)\end{array}$ & $\begin{array}{c}938 \\
(734-1293)\end{array}$ & $1.9 \pm 0.15$ & $1.8 \pm 0.14$ & 2.4 & 2.6 & 1.0 & 16.8 \\
\hline Pymetrozine & $\begin{array}{c}9.4 \\
(8.1-10.9)\end{array}$ & & $\begin{array}{c}44.0 \\
(34.1-61.8)\end{array}$ & & $1.9 \pm 0.16$ & & 1.9 & & 335 & \\
\hline Dinotefuran & $\begin{array}{c}4.6 \\
(3.8-5.6)\end{array}$ & & $\begin{array}{c}34.0 \\
(23.7-57.0)\end{array}$ & & $1.5 \pm 0.15$ & & 3.3 & & 679 & \\
\hline
\end{tabular}

$\mathrm{LC}_{50}$-lethal concentration that kills $50 \%$ of insects, $\mathrm{LC}_{90}$-lethal concentration that kills $90 \%$ of insects, LCL-lower confidence limit, UCL—upper confidence limit, $\chi 2$ = Chi-square value, PL—potency level, SE—standard error, EO—essential oil, and NE—nanoemulsion. 
It should also be noted that marjoram oil and nanoemulsions with $\mathrm{LC}_{50}$ values of 3624 and $221 \mathrm{mg} / \mathrm{L}$ were the least effective after $72 \mathrm{~h}$ (Table 5). In addition, the field strain was less sensitive to the insecticides tested than the laboratory strain. The results cleared that pymetrozine and dinotefuran were the most effective against field strain of A. craccivora with $\mathrm{LC}_{50} 12.5 \mathrm{and} 27.4 \mathrm{mg} / \mathrm{L}$ with significant differences between treatments (Table 5). At all treatments, the toxicity increased dramatically with increasing exposure time. Moreover, the population of $A$. craccivora field strain reflected the different degrees of homogeneity in response to tested with slope values ranged varied from 1.6 to 2.4 (Table 5). Concerning of resistance ratio of the tested essential oils and their nanoemulsions revealed that the field strain of $A$. craccivora had a low level of resistance to all the tested essential oils and their nanoemulsions. Where, these results suggested that basil, cumin, and their nanoemulsions can be used to control $A$. craccivora as a safer and effective insecticide with varying modes of action targeting aphid. The obtained results are in agreement with [42], they showed that the field population of $A$. craccivora exhibited low resistance to acetamiprid, imidacloprid, primiphose-methyl, Pymetrozine, and primicarb ranged from 1.29- to 2.78-fold. In general, the laboratory strain was more susceptible to the tested oils than that the field strain of A. craccivora. Essential oils were promising against many insects, but it had registered some problems i.e., the rate of essential oils, water solubility, and oxidation play a pivotal role in its application and efficiency, therefore, nano-formulation can resolve many problems in essential oils application, where nanoparticles lead to keep the essential oils from degradation, improve their residue half-life by decreasing evaporation, high surface area, solubility, and mobility [43]. The positive effect of these compounds (neemix and basil oil) may be due to their effects on the prolongation of nymph duration and decreasing the number of adults of $A$. craccivora; also the changes in biochemical biomarkers (aspartate transaminase, AST; alanine transaminase, ALT; and alkaline phosphatase ALP) in A. craccivora [44]. Basil showed insecticidal activity in controlling $A$. Craccivora in faba bean plants systematically or by contact, caused toxicity to the adult stage of $A$. craccivora and the accumulative mortality reached $100 \%$ after 7 days of treatment [44].

Table 5. Toxicity of four essential oils, nanoemulsions, and chemical insecticides against $A$. craccivora field strains.

\begin{tabular}{|c|c|c|c|c|c|c|c|c|c|c|}
\hline \multirow{2}{*}{ Treatments } & \multicolumn{2}{|c|}{$\begin{array}{c}\mathrm{LC}_{50} \mathrm{mg} / \mathrm{L} \\
(95 \% \mathrm{LCL}-\mathrm{UCL})\end{array}$} & \multicolumn{2}{|c|}{$\begin{array}{c}\mathrm{LC}_{90} \mathrm{mg} / \mathrm{L} \\
(95 \% \mathrm{LCL}-\mathrm{UCL})\end{array}$} & \multicolumn{2}{|c|}{ Slope \pm SE } & \multicolumn{2}{|c|}{$x^{2}$} & \multicolumn{2}{|c|}{ PL } \\
\hline & EO & NE & EO & NE & EO & NE & EO & NE & EO & NE \\
\hline $\begin{array}{c}O . \\
\text { basilicum }\end{array}$ & $\begin{array}{c}1376 \\
(1148-1607)\end{array}$ & $\begin{array}{c}54 \\
(43-64)\end{array}$ & $\begin{array}{c}6778 \\
(5628-8541)\end{array}$ & $\begin{array}{c}225 \\
(191-273)\end{array}$ & $1.9 \pm 0.14$ & $2.1 \pm 0.16$ & 2.1 & 1.5 & 2.6 & 67.6 \\
\hline C. cyminum & $\begin{array}{c}2263 \\
(1963-2584)\end{array}$ & $\begin{array}{c}83 \\
(67-99)\end{array}$ & $\begin{array}{c}9873 \\
(8071-12744)\end{array}$ & $\begin{array}{c}535 \\
(419-738)\end{array}$ & $2.0 \pm 0.15$ & $1.6 \pm 0.14$ & 4.6 & 1.9 & 1.6 & 43.6 \\
\hline $\begin{array}{c}\text { M. } \\
\text { chamomilla }\end{array}$ & $\begin{array}{c}2857 \\
(2455-3310)\end{array}$ & $\begin{array}{c}163 \\
(140-188)\end{array}$ & $\begin{array}{c}15,727 \\
(12,104-22,244)\end{array}$ & $\begin{array}{c}856 \\
(670-1179)\end{array}$ & $1.7 \pm 0.14$ & $1.8 \pm 0.14$ & 3.8 & 2.5 & 1.3 & 22.2 \\
\hline $\begin{array}{c}O . \\
\text { marjorana }\end{array}$ & $\begin{array}{c}3624 \\
(3143-4191)\end{array}$ & $\begin{array}{c}221 \\
(194-253)\end{array}$ & $\begin{array}{c}18,541 \\
(14,202-26,419)\end{array}$ & $\begin{array}{c}962 \\
(765-1293)\end{array}$ & $1.8 \pm 0.15$ & $2.0 \pm 0.15$ & 2.4 & 1.9 & 1.0 & 16.3 \\
\hline Pymetrozine & $\begin{array}{c}12.5 \\
(10.7-14.3)\end{array}$ & & $\begin{array}{c}49.1 \\
(40.0-64.0)\end{array}$ & & $2.2 \pm 0.18$ & & 2.2 & & 291.1 & \\
\hline Dinotefuran & $\begin{array}{c}27.4 \\
(23.9-31.1)\end{array}$ & & $\begin{array}{c}94.1 \\
(78.1-119.4)\end{array}$ & & $2.4 \pm 0.19$ & & 2.5 & & 132.4 & \\
\hline
\end{tabular}

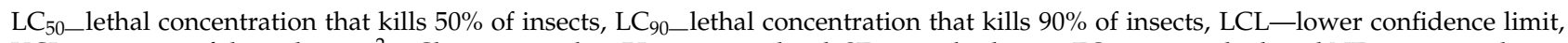
UCL—upper confidence limit, $\chi^{2}=$ Chi-square value, PL—potency level, SE—standard error, EO-essential oil, and NE—nanoemulsion.

\subsection{Inhibitory Activity Evaluation of Essential Oils and Synthesized Nanoemulsions on Insect Enzymes}

The activities of essential oils and synthesized nanoemulsions on the biochemical ingredients (acetylcholine esterase, alkaline phosphatase, beta esterase, glutathione Stransferase, and mixed-function oxidase) of a field strain of aphid A. craccivora were tested and the results are showed in (Figure 5). The treated samples with essential oils showed decreasing in the activity of acetylcholine esterase compared to the control group, where the acetylcholine esterase activity values of control and basil oil were 20.1 and $12.6 \mathrm{ug} / \mathrm{min} / \mathrm{mg}$ 
protein, respectively. However, the level of acetylcholine esterase significantly reduced after the treatment with all four nanoemulsions as compared with the control group (Figure 5A). The toxicity of tested compounds inhibited AChE involved in the process of catalyzing the hydrolysis of the neurotransmitter AChE at nerve synapses and neuromuscular junctions and their activity. The inhibition of acetylcholine esterase activity was confirmed after treated against $A$. Aegypti by $\alpha$-chitin nanoparticles (CNP) [30]. On the other hand, as shown in (Figure 5B,C), the exposure of aphid insects to basil and cumin essential oils and their nanoemulsions resulted in the reduction of the level of alkaline phosphatase and beta esterase activities when compared with the control groups. In the alkaline phosphatase assay, the level of alkaline phosphatase activity decreased from the absorbance value of control 18.7 to values of cumin EO and cumin NE 11.3 and $11.6 \mathrm{mU} / \mathrm{mg}$ protein, respectively. Whereas in the beta esterase assay, the control, basil NE, and cumin NE against aphid insects showed absorbance values of 51.4, 20.4, and $24.5 \mathrm{ug} \beta$-naphthol/min/mg protein, respectively.

Alkaline phosphatase and beta esterase play an important role in the hydrolytic cleavage of phosphoric acid esters and they regulated the alkaline balance [12]. Moreover, these enzymes are important for many remarkable physiological processes such as metabolism and cellular signaling processes [16]. Esterases are the primary enzymes involved in the development of resistance mechanisms to chemical insecticides by splitting the carboxyl ester and phosphodiester bonds. The detoxifying activity of $\beta$-carboxylesterase was used as biomarkers in studies with different insects $[45,46]$. According to the presented data in Figure 5D,E, the exposure of essential oils and synthesized nanoemulsions increased GST and MFO activity in the laboratory and field strains of aphid A. craccivora when compared with control groups. The activity of GST increased in chamomile EO, chamomile NE, marjoram EO, and marjoram NE with values 5.8, 5.4, 6.2, and 5.3 mmole sub. conjugated $/ \mathrm{min} / \mathrm{mg}$ protein, respectively, but in basil $\mathrm{EO}$, basil $\mathrm{NE}$, and cumin $\mathrm{NE}$ the values decreased where were $3.8,2.8$, and $4.0 \mathrm{mmole}$ sub. conjugated $/ \mathrm{min} / \mathrm{mg}$ protein, when compared to control groups $4.1 \mathrm{~m}$ mole sub. conjugated $/ \mathrm{min} / \mathrm{mg}$ protein, respectively. Furthermore, the effectiveness of mixed-function oxidase increased in all essential oils and their nanoemulsions except chamomile EO 999.3, marjoram EO $931 \mathrm{u}$ mole sub. oxidized $/ \mathrm{min} / \mathrm{mg}$ protein, when compared with control groups $1021 \mathrm{u}$ mole sub. oxidized $/ \mathrm{min} / \mathrm{mg}$ protein. The MFO activity values of aphid $A$. craccivora were 1724.7, 1525.7, 1344.3, 1213.3, and $1053.3 \mathrm{u}$ mole sub. oxidized/min/mg protein for basil $\mathrm{NE}$, cumin NE, basil EO, chamomile NE, and marjoram NE, respectively. In previous studies, the detoxification enzyme system, known as the mixed-function oxidase system, protect insects from poisons. Moreover, lepidopterous larvae show that the MFO system is an effective biochemical defense, mainly because this system plays an important role in the primary degradation and inactivation of a wide variety of exogenous lipophilic substances, the high concentration of these enzymes occurs in plant-eating insects, in which they detoxify the natural toxins in the plants $[47,48]$. 

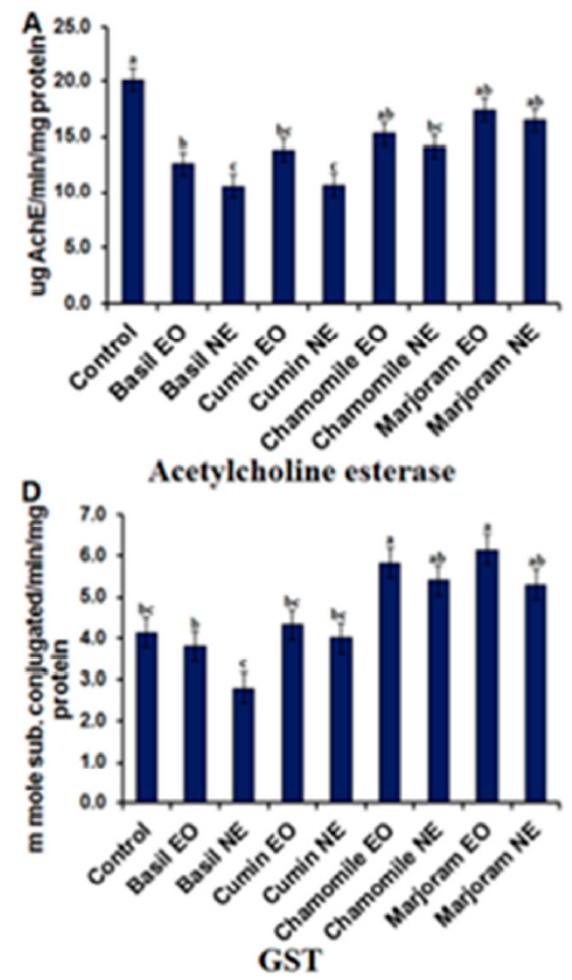

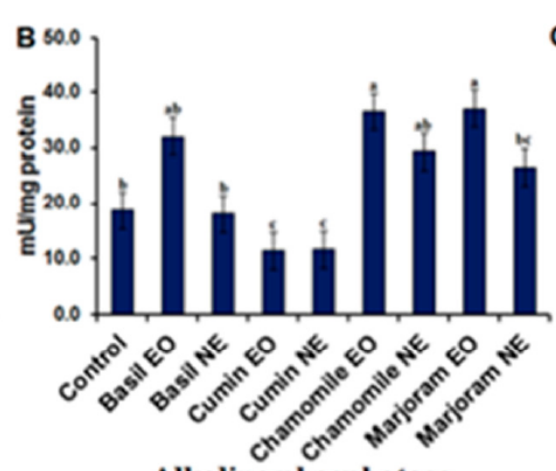

Alkaline phosphatase

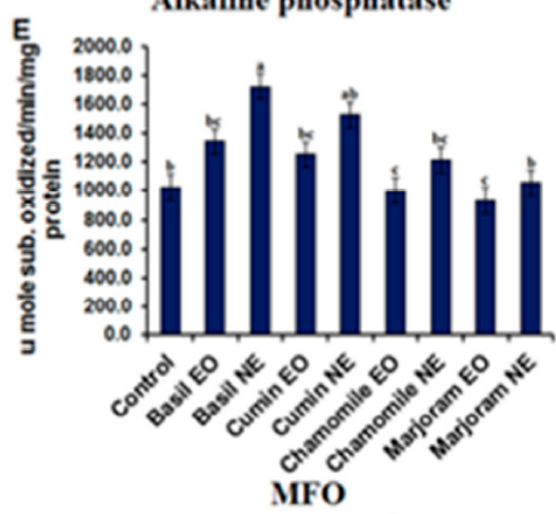

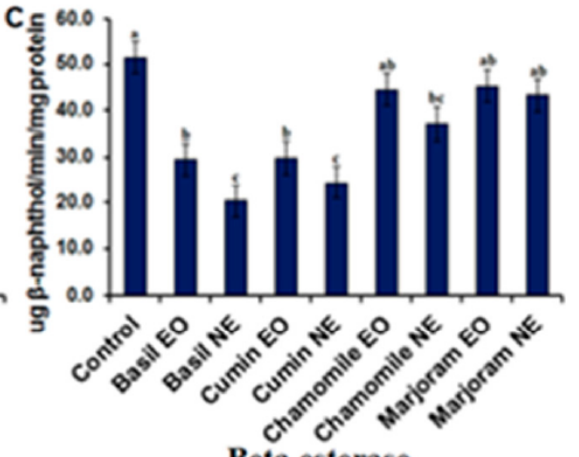

Beta esterase

Figure 5. Impact of four essential oils and their nanoemulsions on enzyme activities. (A) acetylcholine esterase, (B) alkaline phosphatase, (C) $\beta$-esterase, (D) glutathione S-transferase (GST), and (E) mixed-function oxidase (MFO) enzymes. Each bar represents the mean $\pm S E$ of three replicates using different preparations of insect homogenates $(a, a b$, and $b c)$.

\section{Conclusions}

In the current study, we synthesized nanoemulsion as environmentally friendly organic natural compounds and compared them with two selective insecticides dinotefuran, pymetrozine, and essential oils. The TEM image of basil NE, chamomile NE, marjoram NE, and cumin NE, indicated that the synthesized emulsion nanoparticles are mainly uniform with a spherical shape. Furthermore, the EDX pattern of nanoemulsion was indicated, where the presence of strong peaks of different elements that $\mathrm{Ca}, \mathrm{Cu}, \mathrm{Zn}, \mathrm{K}$, and $\mathrm{Mg}$ were the major elements in nanoemulsion, thus confirming the successful of nanoemulsion. Furthermore, the obtained oils and their nanoemulsions showed considerable toxicity against laboratory and field strains of cowpea aphid A. craccivora with the highest mortality rate of nanoemulsions when compared with their essential oils and also at the same time with synthetic insecticides. All this is due to the high efficiency of nanoemulsions, their small size, and their ability to penetrate the body of the pest. Moreover, the inhibitory activity evaluation of essential oils and synthesized nanoemulsion on insect enzymes showed that the treated samples showed decreased activity of acetylcholine esterase when compared to the control groups. Further studies are required to characterize the interaction pathway between nanoemulsion and the cell organelles including mitochondria and the nucleus. Thus, the synthesized nanoemulsion may be employed as an eco-friendly insecticide and at low dosages to control cowpea aphid in faba bean fields and protect the environment.

Author Contributions: Conceptualization, A.Q., and M.E.; methodology, K.A., Y.H.; F.A.; writingoriginal draft preparation, H.M., K.S., H.F.; writing-review and editing, Y.H., K.A.; supervision, K.A., H.M., K.S., H.F.; funding acquisition, F.A.S.H., K.A., Y.H., K.S. All authors have read and agreed to the published version of the manuscript.

Funding: The authors acknowledge Taif University Researchers Supporting Project number (TURSP2020/143), Taif University, Taif, Saudi Arabia. The authors extend their appreciation to the Plant Pathology and Biotechnology Lab., (ISO/17025 Accredited) and EPCRS Excellence Centre (Certified 
according to ISO/9001, ISO/14001, and OHSAS/18001), Dept. of Agric. Botany, Fac. of Agric., Kafr-Elsheikh University, Kafr-Elsheikh, Egypt.

Institutional Review Board Statement: Not applicable.

Informed Consent Statement: Not applicable.

Conflicts of Interest: The authors declare no conflict of interest.

\section{References}

1. Togola, A.; Boukar, O.; Belko, N.; Chamarthi, S.K.; Fatokun, C.; Tamo, M.; Oigiangbe, N. Host plant resistance to insect pests of cowpea (Vigna unguiculata L. Walp.): Achievements and future prospects. Euphytica 2017, 213, 239. [CrossRef]

2. Van Emden, H.F.; Harrington, R. (Eds.) Aphids as Crop Pests; Cabi: Wallingford, Oxfordshire, UK; Boston, MA, USA, 2017.

3. Li, F.; Han, Z. Mutations in acetylcholinesterase associated with insecticide resistance in the cotton aphid, Aphis gossypii Glov-er. Insect Biochem. Mol. Biol. 2004, 34, 397-405. [CrossRef] [PubMed]

4. Isman, M.B. Botanical insecticides, deterrents, and repellents in modern agriculture and an increasingly regulated world. Annu. Rev. Ėntomol. 2006, 51, 45-66. [CrossRef] [PubMed]

5. Ambethgar, V. Potential of entomopathogenic fungi in insecticide resistance management (IRM): A review. J. Biopestic. 2009, 2, 177-193.

6. Govindarajan, M.; Mathivanan, T.; Elumalai, K.; Krishnappa, K.; Anandan, A. Ovicidal and repellent activities of botanical ex-tracts against Culex quinquefasciatus, Aedes aegypti and Anopheles stephensi (Diptera: Culicidae). Asian Pac. J. Trop. Biomed. 2011, 1, 43-48. [CrossRef]

7. Ga'Al, H.; Fouad, H.; Mao, G.; Tian, J.; Jianchu, M. Larvicidal and pupicidal evaluation of silver nanoparticles synthesized using Aquilaria sinensis and Pogostemon cablin essential oils against dengue and zika viruses vector Aedes albopictus mosquito and its histopathological analysis. Artif. Cells Nanomed. Biotechnol. 2017, 46, 1171-1179. [CrossRef] [PubMed]

8. Fouad, H.; Hongjie, L.; Yanmei, D.; Baoting, Y.; El-Shakh, A.; Abbas, G.; Jianchu, M. Artificial Cells, Nanomedicine, and Bio-technology. Cocos Nucifera 2017, 1369-1378.

9. Liu, Z.; Han, Z. Fitness costs of laboratory-selected imidacloprid resistance in the brown planthopper, Nilaparvata lugens Stål. Pest Manag. Sci. 2006, 62, 279-282. [CrossRef]

10. Mokbel, E.M.S.; Swelam, E.S.H.; Radwan, E.M.M.; Kandil, M.E. Role of metabolic enzymes in resistance to chlorpyrifos-methyl in the cowpea aphid, Aphis craccivora (Koch). J. Plant Prot. Res. 2017, 57, 275-280. [CrossRef]

11. Fouad, H.; Hongjie, L.; Hosni, D.; Wei, J.; Abbas, G.; Ga'Al, H.; Jianchu, M. Controlling Aedes albopictus and Culex pipiens pallens using silver nanoparticles synthesized from aqueous extract of Cassia fistula fruit pulp and its mode of action. Artif. Cells Nanomed. Biotechnol. 2018, 46, 558-567. [CrossRef]

12. Ga'Al, H.; Yang, G.; Fouad, H.; Guo, M.; Mo, J. Mannosylerythritol Lipids Mediated Biosynthesis of Silver Nanoparticles: An Eco-friendly and Operative Approach against Chikungunya Vector Aedes albopictus. J. Clust. Sci. 2021, 32, 17-25. [CrossRef]

13. Pandey, A.K.; Tripathi, S.; Singh, P. Plant essential oils: A substitute for conventional insecticides against Tribolium species (Coleoptera: Tenebrionidae)-achievements and challenges. Arch. Phytopathol. Plant Prot. 2018, 51, 696-728. [CrossRef]

14. Pavela, R. History, presence and perspective of using plant extracts as commercial botanical insecticides and farm products for protection against insects-a review. Plant Prot. Sci. 2016, 52, 229-241.

15. Benelli, G.; Pavela, R.; Giordani, C.; Casettari, L.; Curzi, G.; Cappellacci, L.; Petrelli, R.; Maggi, F. Acute and sub-lethal toxicity of eight essential oils of commercial interest against the filariasis mosquito Culex quinquefasciatus and the housefly Musca domestica. Ind. Crop. Prod. 2018, 112, 668-680. [CrossRef]

16. Nathan, S.S.; Kalaivani, K.; Chung, P.G. The effects of azadirachtin and nucleopolyhedrovirus on midgut enzymatic profile of Spodoptera litura Fab. (Lepidoptera: Noctuidae). Pestic. Biochem. Physiol. 2005, 83, 46-57. [CrossRef]

17. Pavela, R.; Žabka, M.; Vrchotová, N.; Tř́ska, J. Effect of foliar nutrition on the essential oil yield of Thyme (Thymus vulgaris L.). Ind. Crop. Prod. 2018, 112, 762-765. [CrossRef]

18. Cespi, M.; Quassinti, L.; Perinelli, D.R.; Bramucci, M.; Iannarelli, R.; Papa, F.; Ricciutelli, M.; Bonacucina, G.; Palmieri, G.F.; Maggi, F. Microemulsions enhance the shelf-life and processability of Smyrnium olusatrum L. essential oil. Flavour Fragr. J. 2017, 32, 159-164. [CrossRef]

19. Hamouda, T.; Hayes, M.M.; Cao, Z.; Tonda, R.; Johnson, K.; Wright, D.C.; Brisker, J.; Baker, J.R., Jr. A novel surfactant nanoemulsion with broad-spectrum sporicidal activity against Bacillus species. J. Infect. Dis. 1999, 180, 1939-1949. [CrossRef]

20. Joe, M.M.; Bradeeba, K.; Parthasarathi, R.; Sivakumaar, P.K.; Chauhan, P.S.; Tipayno, S.; Benson, A.; Sa, T. Development of surfactin based nanoemulsion formulation from selected cooking oils: Evaluation for antimicrobial activity against selected food associ-ated microorganisms. J. Taiwan Inst. Chem. Eng. 2012, 43, 172-180. [CrossRef]

21. Busvine, J.R. Recommended Methods for Measurement of Pest Resistance to Pesticides; Busvine, J.R., Ed.; FAO: Rome, Italy, 1980.

22. Harlow, C.D.; Lampert, E.P. Resistance Mechanisms in Two Color Forms of the Tobacco Aphid (Homoptera: Aphididae). J. Econ. Ėntomol. 1990, 83, 2130-2135. [CrossRef]

23. Abbott, W.S. A method of computing the effectiveness of an insecticide. J. Econ. Entomol. 1925, 18, 265-267. [CrossRef]

24. Finney, D.J. Probit Analysis; Cambridge University Press: Cambridge, UK, 1971.

25. Van Asperen, K. A study of housefly esterases by means of a sensitive colorimetric method. J. Insect Physiol. 1962, 8, 401-416. [CrossRef] 
26. Habig, W.H.; Pabst, M.J.; Jakoby, W.B. Glutathione Stransferases. The first enzymatic step in mercapturic acid formation. J. Biol. Chem. 1974, 249, 7130-7139. [CrossRef]

27. Powell, M.E.A.; Smith, M.J.H. The Determination of Serum Acid and Alkaline Phosphatase Activity with 4-Aminoantipyrine (A.A.P.). J. Clin. Pathol. 1954, 7, 245-248. [CrossRef]

28. Hansen, L.G.; Hodgson, E. Biochemical characteristics of insect microsomes: N-and O-demethylation. Biochem. Pharmacol. 1971, 20, 1569-1978. [CrossRef]

29. Amin, T.R. Biochemical and Physiological Studies of Some Insect Growth Regulators on the Cotton Leafworm, Spodoptera Littoralis (Boisd.). Ph.D. Thesis, Cairo University, Giza, Egypt, 1998.

30. Solairaj, D.; Rameshthangam, P. Silver nanoparticle embedded $\alpha$-chitin nanocomposite for enhanced antimicrobial and mos-quito larvicidal activity. J. Polym. Environ. 2017, 25, 435-452. [CrossRef]

31. Yuan, C.-G.; Huo, C.; Gui, B.; Liu, P.; Zhang, C. Green Synthesis of Silver Nanoparticles Using Chenopodium aristatum L. Stem Extract and Their Catalytic/Antibacterial Activities. J. Clust. Sci. 2016, 28, 1319-1333. [CrossRef]

32. Manjamadha, V.P.; Muthukumar, K. Ultrasound assisted green synthesis of silver nanoparticles using weed plant. Bioprocess Biosyst. Eng. 2016, 39, 401-411. [CrossRef]

33. Deepak, P.; Sowmiya, R.; Ramkumar, R.; Balasubramani, G.; Aiswarya, D.; Perumal, P. Structural characterization and evaluation of mosquito-larvicidal property of silver nanoparticles synthesized from the seaweed, Turbinaria ornata (Turner) J. Agardh 1848. Artif. Cells Nanomed. Biotechnol. 2017, 45, 990-998. [CrossRef]

34. Benelli, G.; Govindarajan, M.; Rajeswary, M.; Senthilmurugan, S.; Vijayan, P.; Alharbi, N.S.; Kadaikunnan, S.; Khaled, J.M. Larvicidal activity of Blumea eriantha essential oil and its components against six mosquito species, including Zika virus vectors: The promising potential of (4E,6Z)-allo-ocimene, carvotanacetone and dodecyl acetate. Parasitol. Res. 2017, 116, 1175-1188. [CrossRef]

35. Bedini, S.; Flamini, G.; Cosci, F.; Ascrizzi, R.; Benelli, G.; Conti, B. Cannabis sativa and Humulus lupulus essential oils as novel con-trol tools against the invasive mosquito Aedes albopictus and fresh water snail Physella acuta. Ind. Crop. Prod. 2016, 85, 318-323. [CrossRef]

36. Lett, A.M. Microstructure Engineering of Emulsion-Based Systems for the Control of Satiation, Satiety, Hedonic Acceptability and Sensory Quality. Ph.D. Thesis, University of Birmingham, Birmingham, UK, 2016.

37. Bordes, P.; Pollet, E.; Avérous, L. Nano-biocomposites: Biodegradable polyester/nanoclay systems. Prog. Polym. Sci. 2009, 34, 125-155. [CrossRef]

38. Marques, M.G.; Landim, T.N.; Silva, S.M.; Cunha, J.P.A.R.; Sampaio, M.V. Toxicidade do óleo essencial de Ocimum basilicum combinado ao inseticida tiametoxam para o pulgão-do-algodoeiro. Revista Brasileira de Ciências Agrárias (Agrária) $2019,14,5651$.

39. Pandey, A.K.; Singh, P.; Tripathi, N.N. Chemistry and bioactivities of essential oils of some Ocimum species: An overview. Asian Pac. J. Trop. Biomed. 2014, 4, 682-694. [CrossRef]

40. Chenni, M.; El Abed, D.; Rakotomanomana, N.; Fernandez, X.; Chemat, F. Comparative Study of Essential Oils Extracted from Egyptian Basil Leaves (Ocimum basilicum L.) Using Hydro-Distillation and Solvent-Free Microwave Extraction. Molcules 2016, 21, 113. [CrossRef]

41. Muráriková, A.; Ťažký, A.; Neugebauerová, J.; Planková, A.; Jampílek, J.; Mučaji, P.; Mikuš, P. Characterization of essential oil composition in different basil species and pot cultures by a GC-MS method. Molecules 2017, 22, 1221. [CrossRef]

42. Ahmed, M.; Qin, P.; Ji, M.; An, R.; Guo, H.; Shafi, J. Spinasterol, 22,23-Dihydrospinasterol and Fernenol from Citrullus colocynthis, L. with Aphicidal Activity against Cabbage Aphid Brevicoryne Brassicae, L. Molcules 2020, 25, 2184. [CrossRef]

43. González, J.O.W.; Gutiérrez, M.M.; Ferrero, A.A.; Band, B.F. Essential oils nanoformulations for stored-product pest controlCharacterization and biological properties. Chemosphere 2014, 100, 130-138. [CrossRef]

44. Abdel-Aziz, N.F.; Abdou, W.L.; Abdel-Hakim, E.A.; El-Hawarya, F.M.; El-Bakry, A.M.; Sammour, E.A. The effect of some green insec-ticides from essential oils on Aphis craccivora, and their side effects. J. Entomol. Res. 2015, 39, 275-286. [CrossRef]

45. Pradeepa, V.; Senthil-Nathan, S.; Sathish-Narayanan, S.; Selin-Rani, S.; Vasantha-Srinivasan, P.; Thanigaivel, A.; Ponsankar, A.; Edwin, E.S.; Sakthi-Bagavathy, M.; Kalaivani. K.; et al. Potential mode of action of a novel plumbagin as a mosquito re-pellent against the malarial vector Anopheles stephensi (Culicidae: Diptera). Pestic. Biochem. Physiol. 2016, 134, 84-93. [CrossRef]

46. Selin-Rani, S.; Senthil-Nathan, S.; Revathi, K.; Chandrasekaran, R.; Thanigaivel, A.; Vasantha-Srinivasan, P.; Ponsankar, A.; Edwin, E.S.; Pradeepa, V. Toxicity of Alangium salvifolium Wang chemical constituents against the tobacco cutworm Spodoptera litu-ra Fab. Pestic. Biochem. Physiol. 2016, 126, 92-101. [CrossRef] [PubMed]

47. Amutha, C.; Bupesh, G.; Ramesh, R.; Kavitha, P.; Subramanian, P. Cytochrome P450-Dependent Mixed Function Oxidases (MFO) System Dynamics During the Poly Aromatic Hydrocarbon (PAH) Metabolism in Green Mussel Perna Viridis (Linnaeus, 1758). Environ. Bioindic. 2009, 4, 97-116. [CrossRef]

48. Kehrer, J.; Robertson, J.; Smith, C. Free Radicals and Reactive Oxygen Species. Compr. Toxicol. 2010, 277-307. [CrossRef] 